\title{
Historical Politics and Court Redress in the Baltic States
}

\section{Agata Fijalkowski ${ }^{1}$}

This chapter examines the Baltic states' efforts to frame and interpret communist-era crimes through the lens of three European Court of Human Rights (ECtHR) decisions. The cases were driven by petitions from citizens from Estonia, Latvia and Lithuania who, after 1991, failed to get redress in domestic courts on issues related to communist-era actions and offenses. The verdicts in themselves are documents that reflect a certain understanding of the history of the region. In other words, both the decisions and the ways in which communistera actions are characterized as actionable crimes according to domestic and international law constitute important practices of transitional justice.

This chapter considers three salient narratives about the communist past: first, the narratives put forth by the Baltic states themselves in which they interpret certain Soviet-era actions as crimes perpetrated by the KGB on the occupied Baltic states; second, the narratives put forward by the defendants in domestic and European courts regarding actionable crimes and who holds responsibility for them; and third, the narratives set out by ECtHR judges in both the verdicts and their dissenting opinions regarding these Soviet-era offenses. All of these narratives and interpretations are important transitional justice documents. This chapter focuses on three ECtHR decisions, and the way they reflect the understanding of past crimes shared by the judges, the prosecutors, and the defense counsels. These external actors label certain actions as crimes (including imprescriptible crimes) and by so doing, they change or consolidate the historical narrative in the country from which the case originated.

In particular, this chapter argues that these court cases illustrate areas in which domestic and international actors contest memory. They demonstrate that the ECtHR judges can have a wide variety of opinions on whether acts perpetrated during Soviet times on the 
territory of the three Baltic states are punishable after 1991. The ECtHR judges come from diverse educational and legal cultural backgrounds, with potential implications on their understanding of $20^{\text {th }}$ century European history. The ECtHR is increasingly playing an important role in the validation of key historical narratives in post-communist Europe, with unexpected consequences for the definition of key crimes and the way these definitions are contested The judiciary's legal interpretation and understanding of international human rights law is crucial in criminal justice cases that entail a conflict between the duty to prosecute heinous crimes and the prohibition of ex-post facto punishment. ${ }^{2}$ To illustrate the way that these changes in definition and legal remedy come about, the chapter engages both the legal reasoning put forward by domestic courts before the cases reach the ECtHR, and the legal reasoning and verdict of the ECtHR on these cases.

At present, the ECtHR includes 47 judges nominated by the states parties to the European Convention of Human Rights. At least 22 judges come from former communist countries and the FSU, including one judge from Russia. A case that comes before the Chamber of the ECtHR is heard by a bench composed of the President of the Section to which the case is assigned, the national judge (the judge with the nationality of the state against which the application is lodged) and five other judges. In exceptional cases, a case may be referred or relinquished to the Grand Chamber. In such a situation, the bench is composed of a larger panel of 17 judges.

In the Baltic republics in particular, and the Former Soviet Union (FSU) more generally, the transition from the repressive communist regimes to more democratic forms of government catalyzed new perspectives on national history. The power struggle between the old and new elites produced different narratives, some shared by the former oppressors, others championed by the former oppressed. The transition also created debates about the significance of key historical events and persons and, more broadly, about right and wrong. 
In this context, the domestic courts have become critical forums in which different versions of the communist history have prevailed at times through the venue of legal cases.

Occasionally, some of the cases related to communist crimes have then moved to international courts, when individuals believed that due process or legal safeguards were not met in their national jurisdiction. As a result, the ECtHR has become an important "dispenser of transitional justice." 3 The "narratives" about the communist past that the ECtHR has heard, produced, and accepted have in turn determined the shape, form and success of an important transitional justice measure: court trials as a method of redress. Interestingly, that redress consequently takes place at the national level, reflecting the manner in which the external framing of measures is nationally situated. While it does not replicate the type of foreign transitional justice seen in the International Criminal Tribunal for the Former Yugoslavia (ICTY), it does represent an important international influence on interpretations of history and justice.

Importantly, versions of history could also be appropriated for varied political ends. ${ }^{4}$ In this chapter, 'historical politics' refers to the political use and abuse of history. An examination of the way in which memories of violent periods are interpreted and used reveals the active appropriation and the use of the past as a basis on which to take prosecutorial action. $^{5}$ All cases considered here concerned retrospective justice, and required the courts to define and debate the communist crimes to see if they amounted to imprescriptible crimes (war crimes, crimes against humanity, and genocide). While retrospective justice is important for transitional justice, since it comprises the key points that underpin it (justice and truth), it is legally complex. The court can be challenged when asked to look at provisions permitting the law to work backwards to address egregious rights violations. The Baltic states illustrate the ways in which transitional justice, legal culture, historical politics, and retrospective justice can come together. Ultimately, these cases point to changes in the way international 
courts interpret communist crimes as imprescriptible crimes. International courts can thus render rulings that impose a different view of history, in contradiction to the domestic courts' interpretation. This chapter highlights the manner in which the ECtHR has shaped legal and political developments and historical narratives in the Baltic states.

\section{The Baltic states and their Soviet past}

Further to the Molotov-Ribbentrop Agreement concluded between the Soviets and the Germans, the Baltic states were militarily occupied and annexed by the Soviet Union in 1940. The states became part of the Soviet Union de facto, although most Western countries refused to recognize this annexation as legal. ${ }^{6}$ The Soviet occupying forces initiated, inter alia, two main repression campaigns in the Baltic states.

During the first occupation of 1940-1941 the Soviets carried out mass deportations in all three countries. In Estonia, it is estimated that 9,267 persons were deported (the number does not include victims of repression or of extra-judicial executions). In Latvia 15,424 persons were deported, and in Lithuania $17,500 .^{7}$ Other forms of widespread repression extended to all segments of the Baltic populations, including the political and economic elites, and racial and religious minorities, such as Jews, Roma and Jehovah's Witnesses. This first repression campaign is often seen as evidence of the Soviet Union's intent to destroy Estonia, Latvia and Lithuania. ${ }^{8}$

During the first twelve years of the second occupation of 1944-1991 further deportations were carried out against local guerrilla movements (the so-called 'forest brethren'), the wealthy peasants (the kulaks), and various religious minorities. ${ }^{9}$ It is estimated that 20,702 Estonians, 42,231 Latvians, and 78,735 Lithuanians were deported during this second wave. ${ }^{10}$ The number of casualties is perhaps even higher, but cannot be estimated in the absence of full access to Russian communist-era archives. Estimates of the total number 
of Baltic inhabitants repressed, executed or deported to remote regions in the Soviet Union in 1940-1953 range from several hundred thousand to over a million, ${ }^{11}$ and do not include the people executed or killed or the thousands who fled westwards upon the return of the Soviet Red Army in $1944 .^{12}$ Archival materials suggest that these deportations were planned and executed by the local Soviet security services at the direct order of Moscow, but could not have taken place without high levels of cooperation on the part of the Estonians, Latvians and Lithuanians. ${ }^{13}$ The Baltic states condemned their incorporation into the Soviet Union as forcible military occupation, and asserted that these two deportation campaigns amounted to genocide by the Soviet occupying regime. It was not until the Soviet Union collapsed in 1991 that state responsibility for Soviet-era crimes became a tangible possibility. During the early 1990s, Russia reached out to the Baltic states to establish joint history commissions. These early attempts were rejected by Estonia and petered out in Latvia, because the Baltic republics were not convinced that such commissions could lead to a meaningful outcome. Under Russian Presidents Dmitry Medvedev (2008-2012) and Vladimir Putin (1999-2008, 2012-present) historical politics included the following:

1) evasive dealings with Stalinism with infrequent critical utterances; 2) tactical 'willingness' to acknowledge historical facts and responsibility (not always offering an apology) of the Soviets for such undeniable criminal actions...; 3) large-scale recreation and popular diffusion of the myth of the 'Great Patriotic War', especially the glorification and self-sacrificing and heroic contribution of the Soviets to the victory against fascism and the liberation of Europe; 4) thorough counteraction against the denial or distortion of 'the results of the Second World War' that were decided and confirmed at Yalta, Potsdam, Nuremberg and Tokyo. ${ }^{14}$

In contrast to the narrative about the past that would comport with Russia's version of the Baltics as willing Soviet Union republics, most people in the Baltic states experienced Soviet 
rule as imposed from the outside. After 1991, the Baltic states pushed a dominant historical narrative that treated the Soviet occupation and the entire Soviet regime as an externally inflicted tragedy. ${ }^{15}$ By so doing, they ignored the large role played by ethnic Estonians, Latvians and Lithuanians in supporting the occupation, consolidating communist rule, and carrying out the surveillance program (see Bekus in this volume). The three court cases discussed in this chapter speak to these aspects of historical politics in post-communist Russia and the Baltics, highlighting the layered and complex history of the Baltics as part of, and oppressed by, the Soviet Union. Since 1991, the oppressed have been rehabilitated by the Estonian, Latvian and Lithuanian states, but the Russian state has rejected both the criminal prosecution of Soviet or Russian offenders and its responsibility to compensate Baltic victims. Russia's rejection of responsibility and compensation has prompted commentators to recall the eagerness with which Nikita Khrushchev condemned Stalinist crimes at the $20^{\text {th }}$ Communist Party Congress in 1956, but not the other crimes perpetrated by the Soviet state

after Stalin's death in $1953 .^{16}$ The selective manner in which some histories are repressed and other histories are validated highlights the potential instrumental use of the past to forge a new national narrative. These tensions are evident in the three ECtHR cases explored in depth in the following section. Court petitions and cases challenge narratives underscoring the Soviet heroism against fascism, and by doing so, in the eyes of the Russian officials, they distort World War II reality. In this way, the Baltic cases are not just about the Baltics, they reverberate through other FSU states, in particular Russia, as they legitimize or reject certain narratives about the past that are critical for state building.

\section{Retrospective justice through the Baltic court cases}

Measures supporting retrospective justice are an important subject of study. Retrospective justice ideally aims at ascertaining the truth and achieving justice, yet not all 
truth and justice policies may automatically contribute to such a process, and the links between truth and justice are varied and require consideration. ${ }^{17}$ Retrospective justice has its roots in the old criminal law principle that the law should not work backwards. This principle was enshrined in Article 7 of the European Convention on Human Rights. ${ }^{18}$ The Convention was formulated in 1950, when its drafters responded to previous developments in Nazi Germany and other parts of Europe that allowed authoritarian regimes to pass retroactive laws that made criminal, without warning, acts that had been lawful under the previous democratic regime. ${ }^{19}$ These developments also resonated after World War II, when the international community developed the Nuremberg principles, further to the Charter of the International Military Tribunal of 8 August 1945, which permitted individuals to be prosecuted for crimes against humanity that had not been criminal according to the Nazi legislation and practice in force at the time when those acts had been committed. ${ }^{20}$ In general, Article 7 prohibits the legislature and the courts from creating or extending the existing law to criminalize acts or omissions that were not illegal at the time of their commission or omission, or to increase a penalty retroactively. It also expects the law to be clearly defined. ${ }^{21}$ Article 7 reads:

No one shall be held guilty of any criminal offence on account of any act or omission which did not constitute a criminal offence under national or international law at the time when it was committed. Nor shall a heavier penalty be imposed than the one that was applicable at the time the criminal offence was committed. This article shall not prejudice the trial and punishment of any person for any act or omission which, at the time when it was committed, was criminal according to the general principles of law recognized by civilized nations. ${ }^{22}$

Criminal law, which is based on individual guilt and is used to confront past injustice, has important retrospective justice components pertaining to legal certainty and clarity that 
will be explored in this piece through court cases. As will become clear in the next section, both the requirement for individual culpability and the reservation that individuals shall not be punished retrospectively mean that certain forms of retrospective justice might sit uneasily with the legal guarantees enshrined in Article 7.

The Nuremberg Trials drew the attention of the international legal community to principles of natural justice, which were eventually embraced by University of Heidelberg law professor Gustav Radbruch, after he rejected the idea that the horrendous acts of the Holocaust (and other crimes) could go unpunished because they were positive laws. Positive laws are laws laid down by statute by a properly instituted and recognized branch of government. To him, the principle of natural justice could be overcome if the contradiction between the laws in force and the need for justice reached an unbearable degree where the statute constituted incorrect law. ${ }^{23}$ Radbruch's solution to this legal conundrum was readily embraced by the international legal community, and allowed for the prosecution of past crimes as a method of transitional justice.

In the Baltic states, retrospective justice has been connected primarily with the crimes committed by the Soviet state and its agents. The use of retrospective justice through court cases demonstrates how certain historical narratives are validated, thereby privileging certain interpretations of the past in a region with layered histories of atrocity. In particular, three rulings handed down by the ECtHR directly engage with regional retrospective justice dilemmas: Kolk and Kislyiy v. Estonia (decision of 17 January 2006), Kononov v. Latvia (decision of 17 May 2010), and Vasiliauskas v. Lithuania (decision of 20 October 2015). ${ }^{24}$ These three cases have been selected for this analysis based on key characteristics that lie at the core of legal arguments: the nature of the crime, the identity of the perpetrator(s) and of the victim(s), as well as the tensions between diverging historical narratives and retrospective justice goals that infringe procedural guarantees and human rights. 
The crimes of concern for these cases were war crimes, crimes against humanity, and genocide. Of special note is the definition and treatment of the crime of genocide. The 1948 United Nations Convention on the Prevention and Punishment of the Crime of Genocide defined that crime very narrowly. ${ }^{25}$ The Convention refers to protected national, ethnical, racial, and religious groups, but in one of the three Baltic cases examined in this chapter, the ECtHR was asked to extend the definition of genocide to include national political groups. The confirmation by the ECtHR of such an extension did not occur. The chapter examines the way crimes were defined and understood by the state prosecutor, defense counsel and the national courts, and whether the ECtHR upheld the state's narrative in its rulings. Such an investigation is pertinent to transitional justice because it demonstrates that redress through the courts can validate or invalidate the official historical narrative of a country.

\section{Estonia}

The Estonian International Commission for the Investigation of Crimes against Humanity (EICICAH) was created in $1998 .{ }^{26}$ Its mandate was to establish the crimes against humanity that occurred in Estonia under the Nazi and Soviet occupation regimes (the German occupation of 1941-1944 and the Soviet occupation 1940-1941 and 1944 onward). Its remit included documentation, not prosecution. In its final report (published in 2008), the Commission used Article 7 of the 1998 Rome Statute of the International Criminal Court, not the Nuremburg definition of 1945 , to define crimes against humanity. While the actions may qualify as genocide under both documents, the choice to use the Rome Statute was justified on the grounds that the crimes researched by the EICICAH fell under the Rome Statute's definitions of war crimes, crimes against humanity and genocide. The decision to use the Rome Statute also avoided the heated debated about the Nuremberg definition requiring a nexus between the crime and war. Thus, the decision was a prudent one, since to tie the 
definition to the Nuremberg principles might have potentially created problems for prosecutors seeking a charge of genocide. The EICICAH began its work in 1998, at the same time as the Commission of Historians in Latvia, and the International Commission for the Evaluation of the Crimes of Nazi and Soviet Occupation Regimes in Lithuania. All three transitional justice bodies used the Rome Statute to legitimate their aims. ${ }^{27}$ By relying on an international treaty, the Baltic states had the confidence to demand the re-evaluation of their historical narratives about World War II. ${ }^{28}$

The 1992 Estonian Constitution established that the general principles and norms of international law were part of the country's domestic law. Before the adoption of the new Criminal Code in 2001, amendments were made to the Soviet Criminal Code (which remained in force in post-communist Estonia) to include crimes against humanity and genocide. Neither crime was known in the Soviet Criminal Code, but after the amendments took force both crimes were included in paragraph $61 .{ }^{29}$ By putting the two concepts together, the resulting definition created confusion with respect to the applicable law. The new Criminal Code's definition referred to the definitions of crimes against humanity and genocide in international law, but also went beyond them. For example, according to the new Code the corpus delicti, or requisite elements of the crime, included acts against social and political groups, defined as "anti-occupation resistance and other social groups." $" 30$ This extension of the internationally accepted definition to include social and political groups was in direct reference to the repressive acts of deportation committed by the Soviet occupation forces in Estonia. Starting in 1996, the Estonian prosecutors initiated criminal proceedings against a number of persons involved in the mass deportation of civilians. In many investigations related to paragraph 61 , most of the defendants had passed away, and in one case the court chose to relieve the defendant from punishment owing to ill health. ${ }^{31}$ 
The applicants in the case of Kolk and Kislyiy v. Estonia were of Estonian and Russian nationalities. Both were charged under paragraph 61 for their participation in the mass deportation of civilians from Estonia to remote areas of the Soviet Union during the Soviet occupation in 1949. Kolk was an investigator in the Ministry of National Security of Soviet Estonia, whereas Kislyiy was an inspector in the Ministry of Interior. The Estonian domestic courts upheld their convictions. Before the ECtHR, the defendants argued that it was not established by the Estonian courts that deportation had been a crime against humanity under international and domestic law in 1949 (as the Soviet Criminal Code in force at the time recognized no such crimes). The applicants questioned the reasonableness that they could foresee, at that time, that they were committing an offense.

In its ruling, the ECtHR upheld the Estonian Supreme Court's reasoning. The ECtHR referred to the loss of statehood as a result of the Molotov-Ribbentrop agreement as an occupation period when Estonia was unable to fulfill its international commitments. The ECtHR observed that the deportation of the civilian population had been expressly recognized as a crime against humanity in the 1945 Charter of the Nuremberg Tribunal. ${ }^{32}$ Although the Nuremberg Tribunal was established for trying the major war criminals of the European Axis countries for the offenses they committed before or during World War II, the universal validity of the principles concerning crimes against humanity was subsequently confirmed by Resolution 95 of the General Assembly of the United Nations adopted in 1946. Paragraph 2 of Article 7 does not prevent the trial and punishment of a person for any act or omission which, at the time it was committed, was criminal according to the general principles of law recognized by civilized nations. Furthermore, the Soviet Union had been a party to the 1945 Nuremberg Charter and a United Nations member when the General Assembly adopted Resolution 95. According to the ECtHR, therefore, it could not be argued that those principles had been unknown to the Soviet authorities. ${ }^{33}$ 
The judgment attracted criticism mainly because of the inconsistencies in the reasoning surrounding the Nuremberg principles. The ECtHR could have more convincingly argued that the applicants' actions were connected to the execution of crimes attributable to the Soviet Union leaders, which fell under the Nuremberg Charter. ${ }^{34}$ In other words, the criminal nature of deportations was inferred from international criminal law, not from the fact that the Soviet officials and leaders had to be aware of the criminal nature of deporting civilians. Under the European Convention regime, for conduct to be punishable it should be set out as such under either national or international law. The ECtHR's position in Kolk and Kislyiy reflects its position on Article 7 paragraph 2, which stipulated that at the time of its commission the act was criminal according to the general principle of law. In cases where only international rules are at play, or when they conflict with domestic criminal law, the requirements of accessibility and foreseeability disappear. The values upholding human dignity, which is a foundational legal value found at every level of the European constitutional legal order and is also the essence of the European Convention on Human Rights, tip the balance in favor of international law, to the detriment of the accessibility and foreseeability of criminal law.

This case is important for thinking about historical memory and politics because these historical events, and accountability for them, rest at the heart of the legal rationale for retrospective justice. The events took place under Soviet occupation, whose legality has been disputed by Estonia and Russia. As such, Kolk and Kislyiy also speaks to larger transitional justice issues in the FSU, because the case confirms the illegality of the Soviet occupation, which was not limited only to the Baltic states, but extended to other FSU republics. Critically, the ECtHR recognized the illegal actions of the occupying power. In so doing, this application of retrospective justice upheld the victims' dignity over other rights specified in Article 7, as well as over the foreseeability clause. Judge Nicolas Bratza (United Kingdom), 
the presiding judge in the case, led the unanimous decision. He is known for his opinions on other key cases, including The Border Guards cases. ${ }^{35}$ In those rulings, Bratza empathized with the defendant and wondered whether the young soldier could have foreseen that his actions at the Berlin Wall would result in a later criminal conviction. Yet Bratza and the ECtHR were more convinced by the German Federal Court of Justice and the Federal Constitutional Court's argument and application of the the Radbruch formula. In Kolk and Kislyiy the ECtHR referred to the "totalitarian communist regime of the Soviet Union that conducted large-scale and systematic actions against the Estonian population" and saw no reason to depart from the Estonian courts' confirmation that the actions constituted crimes against humanity. Kolk and Kislyiy speaks to larger transitional justice issues that court redress can bring a sense of justice and closure to the oppressed (in this instance, the victims of the deportation and the survivors of the occupation and the repressive rule). Despite this important ruling, the ECtHR approach to retrospective justice is not entirely consistent, as will be seen in the next two cases.

\section{Latvia}

In 1993, Latvia amended its Criminal Code. As with Estonia, it collapsed crimes against humanity and genocide into a single article, and expanded the number of protected groups by adding 'social class' as an actionable group in Article 68 paragraph $1 .{ }^{36}$ General principles of international law were incorporated into domestic law. Further to Article 68 paragraph 1 Latvian prosecutors prepared charges against several former Soviet security police officials, in connection with the deportation campaigns from 1940-1941 and in $1949 .{ }^{37}$

The case of Alfons Noviks, a high-ranking officer in the secret police, presents a rare example of a former KGB leader being charged and convicted successfully. He was held responsible for committing genocide against the Latvian people, understood as the complete 
or partial destruction of a group. ${ }^{38}$ The Noviks case acknowledged that common problems for the three Baltic states in pursuing retrospective justice were the absence of witnesses, the passing away of the perpetrators, and/or the lack of material evidence. For Latvia, getting closer to the truth was difficult also because many answers lay potentially hidden in the still unavailable Russian archives. ${ }^{39}$ The Russian leaders proved uncooperative in providing information to facilitate accountability for communist crimes. ${ }^{40}$

The ECtHR decision in the Kononov case also highlighted a certain historical narrative for the Baltic states. In May 1944, Kononov and a partisan group (that is, a group of communists fighting against the German troops), attacked a village whose inhabitants were suspected of collaborating with the Nazis. Kononov, viewed as a war hero in Soviet Latvia, was shocked when he was prosecuted for war crimes in the 1990s. The case against him was highly politicized by the time it reached the ECtHR, because it forced a retelling of historical events that was driven less by World War II realities and more by the needs of various Latvian post-communist institutions to contradict the Soviet narrative and portray Latvia's Soviet annexation as an unlawful occupation. In his statement, Judge Egbert Myjer (the Netherlands) admitted that a judge "should not normally express his private thoughts in relation to a judgment on which he voted. In this exceptional case, however, I think that my comments may at least clarify that there are many ways of thinking behind the legal wording in which this Strasbourg judgment has been drafted."41 The remark is significant, for it questioned the value of retelling historical narratives about World War II, and re-identifying who was on the 'right' or 'wrong' side. If Kononov was 'right', this would challenge the dominant narrative about World War II and the Soviet fight against fascism as told by Russia. ${ }^{42}$ If Kononov was 'wrong', this would reaffirm Latvia's alternative narrative of being an occupied country. The ECtHR ultimately found that Kononov's Article 7 rights were violated. The Latvian government then appealed this verdict. 
In the appeal before the Grand Chamber, the Kononov case hinged on whether the Nuremberg principles constituted a universal standard or if they applied to the victorious Allies only. While the final ruling went on to uphold the view that the Nuremberg principles are universal and applicable to all, it did not follow the precedent set out in Kolk and Kislyiy about the illegality of the Soviet occupation. The Court could have extended this precedent to the Latvian occupation regime, but such a move proved too much for the ECtHR. Instead the case established that individuals who found themselves in between two occupying forces were presented with impossible choices that blurred the distinction between moral and legal duties. ${ }^{43}$ As a result, the ECtHR's observations concerning the alliances that the villagers could have possibly forged with either the Nazi and/or the Soviet occupiers become hollow. ${ }^{44}$ In other words, the identification of who is the victim and who is the perpetrator of crimes against humanity becomes a complex issue. As this case shows, there were very limited choices to make between two competing occupiers. Is survival a war crime when an individual is trying to stay alive either at the frontline or by giving (under duress at times) information about one warring side to another? The moral ambiguities that arise when stark choices for survival are at play are not addressed in this definition of the crime.

The Kononov case also illustrates competing historical politics. The Russian Federation exercised their right of third party intervention in the case. The Russian officials voiced the sentiments of the partisans, giving the impression that "with whatever methods one fought against Nazism, it was in any case good. ${ }^{, 45}$ For Russia, Kononov's actions were justified because the Soviet takeover of the Baltic states in 1940 was not an illegal occupation and Russia reinforced the positive contribution that was made by individuals like Kononov in the fight against fascism. The multi-layered discourse centered on universal standards and the boundaries of concepts of war crimes and crimes against humanity; the Kononov case shows how Russia's legal thinking is distinct from Europe's mainstream liberalism and its European 
human rights machinery. Russian officials warned, "two or three more judgments concerning revision of the results of World War II - and countries may denounce the [European] Convention [of Human Rights], which will shorten the life-span of the [European] Court.",46 Following a 2015 law that allows constitutional law to take precedence over international law, including the European Convention on Human Rights, Russia is no longer bound to implement the rulings of the ECtHR. ${ }^{47}$ That decision reinforced the divide between European and Russian historical narratives about World War II.

The Latvian and Estonian cases are important for transitional justice because they present differing positions on the same past events as retold by two different parties: the Baltic states and Russia. In both cases the legal provisions for imprescriptible crimes were expanded, but in neither case did the ECtHR really comment on this extension. In Kolk and Kislyiy the ECtHR examined whether crimes against humanity constituted an international law offense at that time of their commission. In Kononov, the ECtHR was keen to show that the Nuremberg principles applied to victors and losers alike, thereby supporting the Nuremberg standard. For historical politics, "legal procedures involving former personnel of the Soviet authorities meant the retelling of past events, from the Soviet forms of narratives to the forms congruous with the regime transition, and constituted an important part of history and memory politics. ${ }^{, 48}$ More generally, "each transition from a repressive regime to more democratic forms of government has led to new perspectives in a country's history. The power struggle between the new and old powers produces different narratives of the oppressor and the oppressed, about the significance of key events and persons and more broadly about right and wrong." ${ }^{49}$ For transitional justice the fact that the ECtHR has become the "dispenser of transitional justice" shows that international courts can render rulings that validate or impose a different view of history, in support of, or in contradiction to, the domestic courts' interpretation. An example of the ECtHR not validating the national courts' 
position is considered in the following section.

\section{Lithuania}

Like Estonia and Latvia, the general principles of international law were incorporated into domestic law, further to the 1992 Lithuanian Constitution. In 1992 Lithuania passed the Law on the Liability for Genocide against the People of Lithuania (to complement ratification of the 1948 Convention and the 1968 New York Convention). ${ }^{50}$ The 1992 law collapsed the crimes committed by the Soviets and the Germans against the Jews and the Lithuanians into one provision, a decision with broad implications for the law's application and the understanding of those historical events. The law was later widened and the newer version served as the basis of the challenge before the ECtHR in the case discussed in this section. Lithuanian lawyers paid close attention to how successful their Estonian and Latvian counterparts were at the ECtHR, and modified their argument in the Algirdas Paleckis case. ${ }^{51}$ As such, in contrast to Estonia, Lithuania had a more coherent legal approach to tackling those issues.

In Vasiliauskas v. Lithuania, the ECtHR found a violation of Article 7. The narrow split vote of 9 to 8 indicated key retrospective justice issues of legal certainty and legal clarity. Vytautas Vasiliauskas was a Lithuanian national retroactively convicted of genocide under Article 99 of the Lithuanian Criminal Code of $2000 .{ }^{52}$ The ruling concerned actions committed in 1953 after the annexation of Lithuania by the Soviet Union. At the center of it were the Lithuanian partisans, defined by the domestic courts as a political group that belonged to the underground resistance against the Soviet regime. Vasilauskas argued that his conviction violated Article 7, pointing to the Lithuanian courts' wide interpretation of genocide, which included political and social groups. Most of the court justices found that the 
conviction under Article 99 of the Lithuanian Criminal Code amounted to a violation of Article 7.

Although genocide was a recognized as a crime under international law in 1953, at the time when the actions were committed, the ECtHR debated whether the applicant's actions qualified as genocide according to the 1948 Convention. The Court held that, in this case, there were no convincing reasons to depart from the groups listed in the 1948 definition. Political groups had been intentionally excluded from the protected categories identified by that definition, a position supported by other international law instruments, such as the Convention on the Non-Applicability of Statutory Limitations to War Crimes and Crimes against Humanity of 1968, the International Criminal Tribunal for the Former Yugoslavia Statute of 1993, and the Rome Statute on the International Criminal Court of 1998.

In turn, the Lithuanian government argued that the Lithuanian partisans were 'part' of a national group (the ethnic Lithuanians), and as such were a protected group. While this argument did not fit with international law, it was consistent with the state narratives about the Soviet occupation of Lithuania. The Lithuanian authorities created a historical commission to research and document this view. With Estonia and Latvia expanding their definitions of genocide, Lithuania did so as well. In its 2003 ruling in the Vasiliauskas v. Lithuania case, the Lithuanian Supreme Court rejected the position that the definition of genocide should be understood narrowly, indicating that the state's accession to the European Convention on Human Rights did not deprive it of its right to interpret the 1948 Convention so as to permit the evaluation of the crimes committed under the Soviet occupation. But the ECtHR adhered to the narrow interpretation, as set out in international law, and rejected the 'part of a part' approach because such an interpretation was not foreseeable to the applicant in 1953, and therefore could not serve as a legal basis for conviction under international law. Thus, the ECtHR concluded that the defendant's Article 7 rights were violated. Moreover, in 
the cases referring to 'in part' normally the distinct part of the protected groups is numerically large in terms of the prominence of the targeted group. In this case, Lithuanians partisans are considered as a distinct part of the wider ethnic Lithuanian group.

The dissenting Judges Mark Villiger (Liechtenstein), Ann Power-Forde (Ireland), Paulo Pinto de Albuquerque (Portugal), and Egidijus Kūris (Lithuania) argued that there had been no violation of Article 7. For these judges, the applicant's conviction was foreseeable in 1953, and the decision to restrict the application of the definition without taking the investigation further was equivalent to adopting an overly formalistic approach. They supported the Lithuanian courts' reasoning that sought a wider approach based on an evaluation of historical facts. In this way, the dissenting judges indicated that Lithuanian partisans were not just a political group, but also a significant part of the national group of ethnic Lithuanians. Therefore, the killing of Lithuanian partisans was consistent with and could be understood as part of the broader objective to destroy ethnic Lithuanians. The judges were convinced of the importance of the partisans in the country's social context, and of the symbolic significance of their destruction to a society that attempted to resist Soviet occupation. For Judge Ineta Ziemele (Latvia), the Kononov ruling provided an important basis upon which to find for Lithuania in the ECtHR consideration of Article 7 standards. The other dissenting judges, András Sajó (Hungary), Nebojša Vučinić (Montenegro) and Ksenija Turković (Croatia), agreed and found the majority view incorrect and misguided. Indeed, in Kononov, the ECtHR approved a standard requiring that offences be defined in law with sufficient accessibility and foreseeability. ${ }^{53}$ Yet in Vasiliauskas, apart from the dissenting judges, historical politics could not find support in the ECtHR.

The divergent majority and minority positions adopted by the judges reveal the divisions even within the ECtHR in defining genocide. The Vasiliauskas v. Lithuania case could result in further challenges under Article 7 of the European Convention of Human 
Rights. Case commentators worry that individuals convicted of genocide by the International Criminal Court (or the International Tribunal for the Former Yugoslavia) may be tempted to challenge their conviction before the ECtHR, relying on Article 7 of the European Convention in holding the state into account for not protecting them properly from the enlarged, domestic interpretation of genocide. ${ }^{54}$ All court judges agreed on the list of protected groups included in the 1948 Convention, but they disagreed on identifying as genocidal the targeting of a part of a part.

In the Stanislovas Drèlingas case from April 2016, the Lithuanian Supreme Court ignored the genocide judgment the ECtHR handed down in the Vasiliauskas case. Drèlingas was convicted for his participation in the capture of Lithuanian partisans, in a plan that was coordinated by the Soviet secret services. Drèlingas was neither the leader of the plan, nor involved in the torture of those captured. He was, however, convicted for genocide of a national-ethno-political group. In its verdict, the Lithuanian Supreme Court only superficially referred to the Vasiliauskas case, and news media outlets failed to note that the ruling contradicted the ECtHR. In the end, Drèlingas's six-year prison sentence was reduced to sixmonths' imprisonment. ${ }^{55}$ Victims and survivors of the Soviet occupation in Lithuania might not be satisfied with the ECtHR decision, but they will most likely applaud the Lithuanian Supreme Court ruling. The Supreme Court, however, is rendering rulings that do not conform to ECtHR decisions, and are arguably unconstitutional. Supporters of retrospective justice will question the inconsistencies that have opened up domestically and internationally as a result of these Lithuanian cases.

\section{Conclusion}

In the Baltic states, transitional justice has included important methods of accountability associated with court trials and verdicts. These methods are not always seen as 
overt and direct forms of transitional justice, but this chapter demonstrated that these cases led to the (re)construction of historical narratives about the Soviet past. In this way, both the domestic court verdicts and their challenges before the ECtHR explored retrospective justice questions related to actions carried out by the Soviet occupying powers in the Baltics. Court rulings validated the Baltic states' narratives with respect to the framing of the offenses as crimes against humanity and/or genocide. The verdicts are documents that reflect a certain understanding of the history of the region, and thus function as a type of transitional justice.

Note that the ECtHR judges and the domestic courts in the Baltic states upheld a wide diversity of opinions on whether acts perpetrated during Soviet times in the Baltic states can be considered as crimes punishable after 1991. The salient areas of contestation were historical narratives, as put forth by the Baltics and by the Russians, and whether the crimes fell under the statutes of limitations. The Baltic retelling of the past was upheld by the ECtHR, but not without some debate about historical contexts, as seen in the Kononov case, before the Chamber and Grand Chamber (see Table 1). In this case, the dominant (Western) European historical narrative, and the Russian position towards its country's contribution in the fight against fascism, was challenged. In fact, Kolk and Kislyiy laid the groundwork for the ECtHR to recognize the illegality of the Soviet occupation of Latvia. It did not do so, but the ECtHR held that the Nuremberg principles apply equally to the Allies and Axis powers alike.

\section{Insert Table 1 around here}

The differences arise in the way that genocide is defined, as seen in Vasiliauskas. There are several issues at stake. One, taken from Vasiliauskas, is whether the Lithuanian definition of genocide that includes national political groups will lead to a change on the part of the ECtHR in its approach to genocide. At present this is a minority view. If not, states (such as Lithuania) will go on to ignore the ECtHR rulings. Without clarity on the part of the 
ECtHR, a state's move to expand a definition of a crime (such as genocide) will mean opening itself up to challenges from those individuals convicted of genocide. This becomes a transitional justice issue for the victims and survivors of a repressive regime, who are hoping for accountability and some sort of validation of their human dignity through the court's (both, or either, domestic and international courts) endorsement of their suffering. All three cases concerned retrospective justice, and debated the definition of war crimes, crimes against humanity and genocide. While the state narratives converged in their position on crimes committed during the Soviet occupation, the ECtHR revealed a less consistent approach in its validation of domestic legal provisions and state historical narratives. While the ECtHR did not confirm the petition (in Vasiliauskas), the split vote demonstrated a possible change in the way that international courts will interpret crimes. Moreover, the three cases involved the ECtHR as the European forum in which these state narratives were challenged and debated.

I argue that through these and other cases, the ECtHR is shaping legal and political developments in the FSU. These three cases demonstrate that the ECtHR has become an important "dispenser of transitional justice," and a critical European forum in which various versions of history prevail at different times. However, the diversity of the ECtHR judges and differences in court practices mean that consistency across cases will not always prevail. Importantly, a court composed of 47 judges will mean differences in approach to the interpretation of the law and in the understanding of peculiar state histories. All three cases saw important contributions from judges representing either former communist states or the FSU, such as Judges Ziemele and Kūris whose dissent strongly criticized a majority position that they saw as narrow, shortsighted, and unable to embrace a wider definition of genocide. The Dutch ECtHR Judge, Egbert Myjer, cannot be ignored. His contribution reflected and supported the Russian position on the Allies' critical role in fighting fascism during World 
War II. This view, as shown in this chapter, is being revised, with the help of the ECtHR. In sum, the decisions depended on the judges' understanding of past crimes, and whether the action qualified as crimes according to domestic and international law.

For the FSU and transitional justice, this points to the selective manner in which some histories are repressed and other histories are validated, highlighting the instrumental use of the past to forge a new national narrative through prosecutorial action. Court petitions and cases challenge narratives underscoring the Soviet heroism against fascism, and by doing so, in the view of the Russian officials, they distort World War II reality. In this way, the Baltic cases are not just about the Baltics. These cases reverberate through other FSU states, in particular Russia, as they legitimize or reject certain narratives about the past that are critical for state-building.

Notes:

\footnotetext{
${ }^{1}$ No new data were created in this study.

${ }^{2}$ Raluca Grosescu and Agata Fijalkowski, "Retrospective Justice and Legal Culture," in Justice, Memory and Redress: New Insights from Romania, eds. Lavinia Stan and Lucian Turcescu (Cambridge: Cambridge Scholars, 2017), 101.

${ }^{3}$ Antoine Buyse and Michael Hamilton, "Introduction," in Transitional Jurisprudence and the ECHR: Justice, Politics, and Rights, eds. Antoine Buyse and Michael Hamilton (Cambridge: Cambridge University Press, 2011), 18 .

${ }^{4}$ Helga Welsh, "Dealing with the Communist Past: Central and East European Experiences after 1990," EuropeAsia Studies, $48: 3$ (1996): 413-428.

${ }^{5}$ Katherine Hite, Cath Collins, and Alfredo Joignant, “The Politics of Memory in Chile," in The Politics of Memory in Chile: From Pinochet to Bachelet, eds. Cath Collins, Katherine Hite, and Alfredo Joignant (Boulder:
} First Forum Press, 2013), 1-29.

${ }^{6}$ Eva-Clarita Pettai and Vello Pettai, Transitional and Retrospective Justice in the Baltic States (Cambridge: Cambridge University Press, 2015, 45.

${ }^{7}$ Ibid., 55 . 
${ }^{8}$ Ibid., 46.

${ }^{9}$ According to the Estonian Supreme Court, "hiding oneself was a form of fighting for independence of the Republic of Estonia and against the injustice done to the Estonian people," cited in Lauri Mälksoo, "Soviet Genocide? Communist Mass Deportations in the Baltic States and International Law," Leiden Journal of International Law, 14 (2001), 776.

${ }^{10}$ Pettai and Vello Pettai, Transitional and Retrospective Justice in the Baltic States, 55.

${ }^{11}$ Ibid, 54.

${ }^{12}$ Idem.

${ }^{13}$ Pettai and Pettai, 2015, 56.

${ }^{14}$ Nobuya Hashimoto, "Maneuvering Memories of Dictatorships and Conflicts," in The Palgrave Handbook of Mass Dictatorship, eds. Paul Corner and Jie-Hyun Lim (London: Palgrave Macmillan, 2016), 179.

${ }^{15}$ Ibid, 58.

${ }^{16}$ Mälksoo, "Soviet Genocide?," 761.

${ }^{17}$ Alexandra Barahona de Brito, Carmen Gonzaléz-Enríquez, and Paloma Aguilar, "Introduction," in The Politics of Memory: Transitioning Justice in Democratizing Societies, eds. Alexandra Barahona de Brito, Carmen Gonzaléz-Enríquez and Paloma Aguilar (Oxford: Oxford University Press, 2001), 2.

${ }^{18}$ European Convention on Human Rights, 2010, available at: http://www.echr.coe.int/Documents/Convention_ENG.pdf (accessed 13 December 2016).

${ }^{19}$ Robin C.A. White and Claire Ovey, Jacobs, White and Ovey: The European Convention on Human Rights (Oxford: Oxford University Press, 2014).

${ }^{20}$ Charter of the International Military Tribunal, 8 August 1945, available at: https://ihldatabases.icrc.org/ihl/INTRO/350?OpenDocument (accessed 13 December 2016).

${ }^{21}$ In Achour v. France, the ECtHR stated that "the criminal law must not be extensively construed to an accused's detriment" (para 41). Achour v. France, Application no. 67335/01, [2007] 45 EHRR 9 (29 March 2006), Charter of the International Military Tribunal, 8 August 1945, available at: https://ihldatabases.icrc.org/ihl/INTRO/350?OpenDocument (accessed 13 December 2016).

${ }^{22}$ Idem.

${ }^{23}$ Peter Quint, "The Border Guards Trials and the East German Past - Seven Arguments," American Journal of Comparative Law, 48(2000), 541-572. 
${ }^{24}$ Kolk and Kislyiy v. Estonia (Application no. 23052/04, decision 17 January 2006), available at: http://echr.ketse.com/doc/23052.04-24018.04-en-20060117/view/ (accessed 4 January 2017), Kononov v. Latvia (Application no. 36376/04, decision 17 May 2010), available at:

http://hudoc.echr.coe.int/eng\#\{"fulltext":["Kononov\%20v\%20Latvia"],"documentcollectionid2":["GRANDCH AMBER"],"itemid":["001-98669"]\} (accessed 4 January 2017) and Vasiliauskas v. Lithuania (Application no. 35343/05, decision 20 October 2015), available at: https://lovdata.no/static/EMDN/emd-2005-035343.pdf (accessed 4 January 2017).

${ }^{25}$ Convention on the Prevention and Punishment of the Crime of Genocide, 12 January 1951, available at: http://www.ohchr.org/EN/ProfessionalInterest/Pages/CrimeOfGenocide.aspx (accessed 17 December 2016).

${ }^{26}$ Introduction, n.d., available at: http://www.mnemosyne.ee/hc.ee/index_frameset.htm (accessed 13 December 2016).

${ }^{27}$ Hashimoto, "Maneuvering Memories of Dictatorships and Conflicts," 174-175.

${ }^{28}$ Ibid., 180.

${ }^{29}$ Estonian Criminal Code, 2001, available at: http://www.legislationline.org/documents/section/criminal-codes (accessed 13 December 2016).

${ }^{30}$ Idem.

${ }^{31}$ Mälksoo, “Soviet Genocide?," 776-781.

${ }^{32}$ Charter of the International Military Tribunal.

${ }^{33}$ Estonia acceded to the 1968 Convention on the Non-Applicability of Statutory Limitations to War Crimes and Crimes against Humanity in 1991 . The 1968 Convention creates the possibility for the state to overcome any obstacle in the form of statute of limitations for these crimes.

${ }^{34}$ Antonio Cassese, "Balancing the Prosecution of Crimes against Humanity and Non-retroactivity of the Law: The Kolk and Kislyiy v. Estonia Case before the ECHR," Journal of International Criminal Justice, 4:2 (2006), 410-418; and Mälksoo, “Soviet Genocide?," 758.

${ }^{35}$ Streletz, Kessler and Krenz v. Germany [2001] 33 EHRR 751, available at: http://www.menschenrechte.ac.at/orig/01_2/Streletz.pdf (accessed 4 January 2017) and K-HW v. Germany [2003] 36 EHRR 108), available at: http://hudoc.echr.coe.int/eng\#\{"appno":["37201/97"],"itemid":["00159352"]\} (accessed 4 January 2017).

${ }^{36}$ Latvian Criminal Code, 1993, available at: http://www.legislationline.org/documents/section/criminal-codes (accessed 14 December 2016). 
${ }^{37}$ In 1995, the Criminal Division for the Investigation of Crimes Committed on Latvian Territory started to investigate Soviet crimes against humanity. It worked closely together with the Centre for the Documentation of the Consequences of Totalitarianism, which was founded in 1992 as research institution.

${ }^{38}$ Katja Wezel, "Latvia’s Soviet Story: Transitional Justice and the Politics of Commemoration,” Satori, 25 October 2009, http://www.satori.lv/raksts/3111 (accessed 17 December 2016).

${ }^{39}$ Lavinia Stan, "The Former Soviet Union," in Transitional Justice in Eastern Europe and the Former Soviet Union, ed. Lavinia Stan (London: Routledge, 2009), 227-230.

${ }^{40}$ Such as the Katyń massacre concerning the execution of Polish prisoners-of-war at various killing sites in 1940 by the Soviet secret police. Janowiec and Others v. Russia, Applications nos. 55508/07 and 29520/09, decision 21 October 2013, available at: http://www.menschenrechte.ac.at/orig/13_5/Janowiec.pdf (accessed 4 January 2017).

${ }^{41}$ Kononov v. Latvia, Application no. 36376/04, [2008] ECHR 695 (24 July 2008), para 10), available at: http://echr.ketse.com/doc/36376.04-en-20080724/view/ (accessed 4 January 2017).

${ }^{42}$ Idem.

${ }^{43}$ Timothy Snyder, Bloodlands: Europe between Hitler and Stalin (London: The Bodley Head, 2010), 391-394.

Kononov v. Latvia, 2010, para 221; Lauri Mälksoo, “Case Commentary,” American Journal of International Law, 105 (2011), 107.

${ }^{45}$ Mälksoo, “Case Commentary,” 107.

${ }^{46}$ Idem.

${ }^{47}$ BBC, "Russia Puts Its Laws above European Court Rulings," 14 July 2015, available at: http://www.bbc.co.uk/news/world-europe-33521553 (accessed 7 November 2016).

${ }^{48}$ Hashimoto, "Maneuvering Memories of Dictatorships and Conflicts," 175.

${ }^{49}$ Antoine Buyse, "The Truth, the Past and the Present: Article 10 and Situations of Transition," in Transitional Jurisprudence and the ECHR: Justice, Politics, and Rights, eds. Antoine Buyse and Michael Hamilton (Cambridge: Cambridge University Press, 2011), 138.

${ }^{50}$ Eva-Clarita Pettai, "Prosecuting Soviet Genocide: Comparing the Politics of Criminal Justice in the Baltic States", European Politics and Society, 17:4 (2016): 1-14, 5-8.

${ }^{51}$ Justinas Žilinskas, "Introduction of the 'Crime of Denial' in the Lithuanian Criminal Law and the First Instances of Its Application,” Jurisprudencija/Jurisprudence, 19:1 (2012), 315-329; Domatas Glodenis, 
“Lithuania's Supreme Court Upholds Verdict for Paleckis'," Lithuania Tribune, 22 January 2013, available at: http://www.liberties.eu/en/news/lithuania-genocide-unlawful-conviction (last accessed 4 January 2017),

${ }^{52}$ Lithuanian Criminal Code, 2003, available at: http://www.legislationline.org/documents/section/criminalcodes (accessed 14 December 2016).

${ }^{53}$ Dissenting opinion Judge Ziemele, Vasiliauskas v. Lithuania, Application no. 35343/05, decision 20 October 2015, para 21, available at: http://lrv-atstovas-eztt.lt/uploads/VASILIAUSKAS_2015_GC_judgment.pdf (accessed 4 January 2017).

${ }^{54}$ Anika Bratzel, “The ECHR's Recent Encounter with Genocide: A Closer Look at the Judgment in Vytautus Vasiliauskas v. Lithuania," 1 December 2015, available at: http://jean-monnet-saar.eu/?p=1100 (accessed 22 December 2016).

${ }^{55}$ Domatas Glodenis, “Lithuanian Supreme Court Ignores Strasbourg Genocide Judgment,” 23 May 2016, available at: http://www.liberties.eu/en/news/lithuania-genocide-unlawful-conviction (accessed 4 January 2017). 